Acta Universitatis Wratislaviensis • No 3982

Literatura i Kultura Popularna XXV, Wrocław 2019

https://doi.org/10.19195/0867-7441.25.25

Katarzyna Kaczor

ORCID: 0000-0003-2897-2904

Uniwersytet Gdański

\title{
Kiedy dziewczyna staje się Jedi. Między ,starymi” a „nowymi” Gwiezdnymi wojnami
}

Słowa kluczowe: „Gwiezdne wojny”, George Lucas, kino popularne, feminizm w kulturze popularnej, kultura popularna XXI wieku

Keywords: Star Wars, George Lucas, popular cinema, feminism in popular culture, popular culture of the 21 st century

\section{Wstęp}

Kiedy w inicjującym ostatnią trylogię „Gwiezdnych wojen” Epizodzie VII: Przebudzeniu Mocy (Star Wars Episode VII: The Force Awakens, reż. J.J. Abrams, USA 2015) na ekranie w pustynnej scenerii planety Jakku pojawia się postać Rey, nie ma wątpliwości, że oto znany z powtórnego opowiedzenia historii Star Treka Jeffrey Jacob Abrams ${ }^{1}$ niemal cztery dekady po premierze Gwiezdnych wojen (Star Wars, reż. G. Lucas, USA 1977)² przedstawi starą-nową opowieść, której bohaterem będzie nie wybraniec, lecz wybranka Mocy. Tym samym w ciągu tego czasu dokonała się swoista rewolucja, w wyniku której zmarginalizowane w oryginalnej trylogii bohaterki w najnowszej stały się protagonistkami.

${ }^{1}$ Szerzej o tym w: K. Kaczor, J. Szyłak, Star Trek (Star Trek: The Motion Pictures), [w:] J. Szyłak et al., Kino Nowej Przygody, Gdańsk 2011, s. 128-129.

2 Gwiezdne wojny były oryginalnym tytułem filmu, którym George Lucas zainicjował pierwszą z trzech trylogii. Po podjęciu w latach dziewięćdziesiątych XX wieku decyzji o zrealizowaniu tak zwanej trylogii prequeli, opowiadających o wydarzeniach, które doprowadziły do powstania Imperium i Ruchu Oporu, usystematyzowano tytulaturę wszystkich zrealizowanych i mających powstać epizodów i od 1997 roku pierwszy ze zrealizowanych filmów nosi tytuł Gwiezdne wojny. Część IV: Nowa nadzieja (Star Wars Episode IV: A New Hope, reż. G. Lucas, USA 1977). 
Przedmiotem niniejszego artykułu jest wskazanie prymarnych aspektów kreacji i ewolucji bohaterek filmowych trylogii z uniwersum „Gwiezdnych wojen” na przykładzie postaci księżniczki Lei, królowej/senator Padme Amidali i nastoletniej Rey. Jednocześnie ich przedstawienia są doskonałym przykładem tego, w jaki sposób w kulturze popularnej są adaptowane i jednocześnie unieważniane postulaty feminizmu, skutkujące emancypacją bohaterek i wskazaną zmianą protagonisty opowieści o zniszczeniu i przywróceniu równowagi Mocy w galaktyce. $\mathrm{Z}$ tego też względu zakres analizy ograniczono do trzech trylogii i ich trzech ikonicznych bohaterek, przy jednoczesnym pominięciu pozostałych tekstów, tworzących rozwijane od 1977 roku uniwersum.

\section{Leia - piękność w opałach}

Kiedy ogląda się inicjujące opowieść o odległej galaktyce i toczącej się w niej wojnie pomiędzy Imperium a dążącymi do przywrócenia demokracji zwolennikami Republiki Gwiezdne wojny. Część IV: Nowa nadzieja, których kontynuacją były Gwiezdne wojny. Czesść V: Imperium kontratakuje (Star Wars Episode V: The Empire Strikes Back, reż. I. Kershneri, USA 1980) i Gwiezdne wojny. Część VI: Powrót Jedi (Star Wars Episode VI: Return of the Jedi, reż. R. Marquand, USA 1983), nie ma się wątpliwości, że jest to męska opowieść, stworzona przez mężczyzn dla mężczyzn. Manifestuje się to przez wybór tematów, jakimi są konflikt zbrojny i motyw inicjacyjnej podróży bohatera, który do pierwszej dekady XXI wieku jest udziałem jedynie postaci wchodzących w wiek męski; uczynienie jej bohaterami mężczyzn: Luke'a, Dartha Vadera, Hana Solo, i znaczącą nieobecność oraz stereotypizację bohaterek kobiecych: księżniczki Lei, ciotki Luke'a — Beru Lars, kanclerz Mon Mothmy i erotycznych niewolnic Jabby.

Fabuła Nowej nadziei skoncentrowana jest wokół podjęcia przez bohaterów misji na skutek wezwania przez „księżniczkę w opałach” i zniszczenia unicestwiającej całe planety Gwiazdy Śmierci. Jak podaje leksykon Kina Nowej Przygody:

Rzecz rozgrywa się w kosmicznym Imperium, gdzie słabe siły Rebelii toczą nierówną walkę z totalitarnym i bezlitosnym systemem władzy. Bohaterem filmu jest mieszkaniec peryferyjnej planety Tatooine, młody chłopak — Luke Skywalker — przypadkiem wciągnięty w wydarzenia, które mają odmienić losy świata. Musi on dowieźć do bazy rebeliantów dwa roboty (R2D2 i C3PO), z których jeden przechowuje plany kosmicznej stacji bojowej zwanej Gwiazdą Śmierci. W wędrówce towarzyszy mu stary rycerz zakonu Jedi — Obi-Wan Kenobi — i dwaj członkowie załogi statku kosmicznego „Sokół Millenium”: Han Solo oraz należący do rasy Wooków włochaty, trzymetrowy Chewbacca. Grupa ta ucieka przed pościgiem prowadzonym przez groźnego Dartha Vadera, trafia na Gwiazdę Śmierci, gdzie uwalnia z lochu piękną księżniczkę Leię, dostarcza plany rebeliantom i bierze udział w zniszczeniu groźnej stacji bojowej. W czasie wędrówki Ben Kenobi uczy Luke'a posługiwania się świetlnym mieczem i Mocą - mistyczną siłą przenikającą cały wszechświat. Wprowadza go również w inne tajniki bycia rycerzem Jedi, ale nie kończy swej nauki, gdyż ginie w pojedynku z Vaderem, 
swoim byłym uczniem, którego opanowała Ciemna Strona Mocy. Jednak i po śmierci Benowi udaje się przemówić do Luke'a, dzięki czemu to właśnie młody Skywalker, posługując się Mocą, unicestwi Gwiazdę Śmierci³.

Należy tutaj dodać, że w finale opowieści tryumfujący członkowie misji, Luke i Han, w nagrodę za uwolnienie i ocalenie księżniczki oraz zniszczenie Gwiazdy Śmierci zostają nie tylko przyjęci do społeczności Rebelii, lecz także przez jej symboliczną przywódczynię przed nią nobilitowani przy dźwięku fanfar.

Twórcy Nowej nadziei, osadzając swoją opowieść w „zmitologizowanej przyszłości”, na co wskazuje implicit napisów początkowych „dawno, dawno temu..." i wykorzystanie ukazującej futurystyczne wizje świata konwencji space opery, kreują bohaterów zgodnie z wzorcami znanym z baśni i opowieści rycerskich. Według kolejności pojawiania się na ekranie:

1. postać odzianej w biel księżniczki Lei, która wysyła wezwanie o pomoc, zostaje uprowadzona i uwięziona przez obleczonego w czerń Dartha Vadera, do momentu uwolnienia jej przez Luke'a i Hana Solo kreowana jest zgodnie z paradygmatem ,piękności w opałach”;

2. okryty czarną zbroją Darth Vader jest zagrażającym królestwu i niewinności księżniczki „złym łotrem”, który uprowadza ją, więzi w swojej siedzibie i łamie zasady kodeksu rycerskiego;

3. odziany w biel Luke - który odczytuje wezwanie Lei, uznaje ją za najpiękniejszą z kobiet i rusza jej z pomocą - jest niewinnym prostaczkiem, podejmującym swój rycerski quest, którego pierwotnym celem jest ocalenie księżniczki i uzyskanie z jej rąk symbolicznej nobilitacji, potwierdzonej prawem do noszenia miecza;

4. z kolei Han Solo, jak zauważył Jerzy Szyłak, jest „,westernowym zabijaką"5, z którym w relacji wizerunek Lei jako „piękności w opałach” jest konsekwentnie dekonstruowany, co uwiarygodnia jej przedzierzgnięcie się po uwolnieniu z Gwiazdy Śmierci w „damę”, która wysyła swoich rycerzy — Luke’a i Hana — z misją ocalenia świata, a po jej wykonaniu przed całą społecznością ich nagradza.

Zainicjowane w Nowej nadziei wątki wstępującego na ścieżkę Mocy Jedi Luke'a i opartej na konflikcie charakterów relacji Hana Solo i Lei zostały rozwinięte w Imperium kontratakuje. Pierwszy (Luke’a) przyjął przebieg właściwy opowieści o inicjacyjnej wędrówce bohatera; drugi zaś (Lei i Hana Solo) odtwarza schemat komedii romantycznej i melodramatu, co w połączeniu z motywem ocalenia księżniczki przed Lordem Vaderem przez Lando Calrissiana unieważniało przypisany pierwotnie jej postaci aspekt aktywny. Jego manifestacją jest zdobycie, przewiezienie i ukrycie przez Leię planów Gwiazdy Śmierci, nagranie we-

${ }^{3}$ K. Kaczor, J. Szyłak, Gwiezdne wojny: Część IV - Nowa nadzieja (Star Wars Episode IV: A New Hope), [w:] J. Szyłak et al., op. cit., s. 103.

4 J. Szyłak, Kino Nowej Przygody — jego cechy i granice, [w:] J. Szyłak et al., op. cit., s. 8.

${ }^{5}$ K. Kaczor, J. Szyłak, Gwiezdne wojny: Część IV..., s. 103. 
zwania do Obi-Wana Kenobiego i wysłanie z misją dostarczenia go mistrzowi Jedi R2D2, co zainicjowało tworzącą oś fabuły Nowej nadziei akcję; jego ikonicznym symbolem jest dzierżony przez bohaterkę blaster, co jest szczególnie widoczne na promujących Nowa nadzieję fotosach oraz okładkach wydawnictw wideo. Zostało to też potwierdzone w początkowych sekwencjach Imperium kontratakuje przez uczynienie jej współdowodzącą bazą na Hoth, a następnie przeprowadzenie przez nią ewakuacji niszczonej bazy oraz naprawienie pilotowanego przez Hana Solo „Sokoła Millenium”, co nie tylko umożliwiło im ucieczkę, lecz także dalszy rozwój akcji.

W następnych sekwencjach Leia staje się jednakże współbohaterką wątku romantycznego i zgodnie z wymogami konwencji w czasie pobytu w Mieście w Chmurach jej funkcjonowanie zostaje podporządkowane dominującemu podmiotowi męskiemu, reprezentowanemu przez: Hana Solo, Landa Calrissiana i Dartha Vadera. Od momentu powitania Lei na lądowisku przez Landa staje się

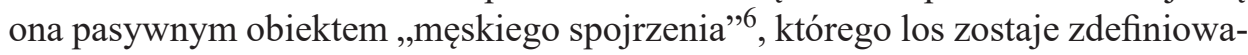
ny przez decyzje trzech mężczyzn. Kwintesencją tego są „męskie pakty” zawarte pomiędzy Darthem Vaderem, Lando Calrissianem i Hanem Solo oraz uprzedmiotowienie księżniczki przez przypisanie jej roli przynęty, mającej zwabić Luke’a do Miasta pod Chmurami. Symbolicznym przywróceniem Lei statusu aktywnego z perspektywy rozwoju fabuły jest pokierowanie przez nią akcją uratowania „wiszącego" w przestrzeni kosmicznej Luke'a, co ocala mu życie i w konsekwencji „umożliwia” kontynuowanie wątku jego konfrontacji z Darthem Vaderem w Powrocie Jedi.

Tematem fabuły Powrotu Jedi jest zakończenie przez Luke’a procesu indywidualizacji, co znajduje wyraz w:

1. figurze śmierci jego mistrza Yody;

2. symbolicznym rozwiązaniu konfliktu edypalnego podczas drugiej konfrontacji z ojcem, którym okazał się Lord Vader;

3. uznaniu swojego dziedzictwa jako syna Anakina Skywalkera/Dartha Vadera.

Natomiast w odniesieniu do romantycznego wątku Lei i Hana Solo to Leia wraz z pozostałymi członkami drużyny powraca na Tatooine, by dokonać nieudanego uwolnienia zamrożonego w karbonicie Hana, w wyniku czego Wookie, „obudzony” jej pocałunkiem Han Solo i Luke trafiają do lochu, a księżniczka jako seksualna niewolnica Jabby (co sugeruje jego lubieżne polizanie jej twarzy i przebranie jej w kostium bohaterek heroic fantasy) zostaje przykuta łańcuchem do jego tronu. Kiedy na pustyni bohaterowie mają zostać rzuceni na pożarcie sarlaccowi, Leia niczym towarzyszka Conana dusi Jabbę łańcuchem, a Luke ich uwalnia, zabi-

6 Jest to termin wprowadzony przez Laurę Malvey dla określenia sposobu kreowania i ukazywania bohaterek w kinie popularnym jako obiektów męskiego pożądania; zob. eadem, Przyjemność wzrokowa a kino narracyjne, przeł. J. Moch, [w:] Panorama wspótczesnej myśli filmowej, red. A. Helman, Kraków 1992, s. 95- 107. 
jając mieczem świetlnym widzów egzekucji. Punktem zwrotnym fabuły Powrotu Jedi jest przystąpienie przez rebeliantów do zniszczenia nowej Gwiazdy Śmierci. O poprowadzenie desantu na księżyc Endor i wyłączenie generatora chroniącego ją pola zostaje poproszony generał Han Solo, podczas gdy Leia zgłasza swój udział w dowodzonej przez niego grupie szturmowej, publicznie uznając przywództwo swojego partnera i symbolicznie zrzekając się funkcji liderki.

Sekwencje desantu na Endor, w którym biorą udział Han Solo, Leia, Luke, Chewbacca, C3PO i R2D2, nie tylko potwierdzają dokonaną pod wpływem wątku romantycznego zmianę paradygmatu, według którego kreowana jest na ekranie postać Lei, w efekcie czego ona i Han Solo stają się współdziałającymi partnerami, lecz także wzbogacają jej postać o aspekt bycia posiadaczką Mocy. Kiedy Leia okazuje się równie dobrym pilotem ścigacza jak Luke, antycypuje to wyjawienie jej przez niego, że ona również odziedziczyła Moc po ich ojcu, którą może się nauczyć posługiwać tak samo jak on, co kobieta kwestionuje. Przypisana Lei niewiara w możliwość posługiwania się przez nią Mocą oznacza niemożliwość bycia rycerzem Jedi przez kobietę, co de facto implikuje niemożliwość pełnienia funkcji głównego bohatera i protagonisty opowieści z cyklu „Gwiezdne wojny” przez postać kobiecą, przy jednoczesnym potwierdzeniu właściwego kulturze patriarchalnej jej służebnego statusu jako ,powierniczki” Mocy, która przekaże ją swojemu potomkowi. Ten stan zmieni się dopiero trzy dekady później, kiedy protagonistką trzeciej z trylogii „Gwiezdnych wojen” zostanie nastoletnia Rey, generał Leia Organa stanie się głównodowodzącą Ruchu Oporu i wykorzysta Moc, by przezwyciężyć śmierć i symbolicznie zmartwychwstać, a tą, która dokona czynu heroicznego, ocalając życie uciekinierów i umożliwiając przetrwanie rebeliantom, będzie ikonicznie kobieca, wystylizowana na rzymską patrycjuszkę wiceadmirał Holdo.

Jak wskazuje Valerie Estelle Frankel w swojej książce Star Wars Meets the Eras of Feminism, sposób kreacji postaci Lei był efektem drugiej fali feminizmu? Miał on na celu przełamanie właściwej bohaterkom fabuł przygodowych bierności przez:

1. przypisanie jej funkcji senatora i zarazem agentki specjalnej ruchu oporu, która dostarczy tajne plany umożliwiające zniszczenie potencjału militarnego Imperium;

2. nadanie jej wysokiego statusu wewnątrz organizacji;

3. wyposażenie jej w zdolność obsługi broni i eliminowania za jej pomocą wrogów,

4. a także poddanie jej torturze patrzenia na zagładę rodzinnej planety, co wskazuje, w jaki sposób w przestrzeni popkultury na przełomie lat siedemdziesiątych i osiemdziesiątych XX wieku adaptowano postulaty drugiej fali femini-

7 Zob. V.E. Frankel, Star Wars Meets the Eras of Feminism. Weighing All the Galaxy's Women Great and Small, Lanham 2018, s. 3-29. 
zmu dotyczące równouprawnienia zawodowego kobiet, a jednocześnie stawiono im opór, negując i odrzucając przez przywoływanie ukonstytuowanych w kulturze wzorców: „piękności w opałach”, „,dziewicy uwięzionej przez złego łotra”, „damy i jej rycerzy, w imię której dokonują oni swoich czynów” oraz „heroiny romansu”.

\section{Padme Amidala — zakochana dziewczyna}

Tej sytuacji, czyli marginalizacji fabularnej funkcji postaci kobiecych w filmowych opowieściach o narodzinach i pokonaniu tyranii w odległej galaktyce, nie zmieniło przedstawienie w latach 1999-2005 drugiej trylogii, którą tworzyły: Gwiezdne wojny. Część I: Mroczne widmo (Star Wars Episode I: The Phantom Menace, reż. G. Lucas, USA 1999), Gwiezdne wojny. Część II: Atak klonów (Star Wars Episode II: Attack of the Clones, reż. G. Lucas, USA 2002), Gwiezdne wojny. Część III: Zemsta Sithów (Star Wars Episode III: Revenge of the Sith, reż. G. Lucas, USA 2005).

Cykl będący prequelem oryginalnej trylogii prezentował opowieść o bohaterze - niepokalanie poczętym wybrańcu Anakinie Skywalkerze, który na skutek swoich wyborów stał się Darthem Vaderem, oraz jego miłosnej relacji z pochodzącą Naboo Padme; zgodnie z dominującym w kinie popularnym lat dziewięćdziesiątych XX wieku trendem był historią o motywowanym pobudkami emocjonalnymi przeistoczeniu się w potwora, zainicjowanym przez Dracule (Bram Stoker's Dracula, reż. F.F. Coppola, USA 1992) i Frankensteina (Mary Shelley's Frankenstein, reż. K. Branagh, USA 1994). Przy czym wątek związku Anakina i Padme jako rodziców Luke'a i Lei w wymiarze osobistym łączy wszystkie pozostałe aspekty ukazywanej na ekranie historii galaktyki: upadku Republiki i narodzin Rebelii oraz zniszczenia zakonu Jedi i przejęcia władzy przez Sithów, wyznawców Ciemnej Strony Mocy.

Padme, jak wskazuje na to V.E. Frankel, jako „królowa Amidala jest manifestacją dziewczęcej siły" ", którą Anita Harris zdefiniowała jako rodzaj energii,

która buduje obecne [przełomu XX i XXI wieku - K.K.] pokolenie młodych kobiet jako wyjątkową kategorię dziewcząt, które są pewne siebie, żyją w sposób odmienny, ale w żaden sposób nienapędzany przez feminizm pod wpływem filozofii „Zrób to sam” i przekonanie, że mogą mieć (lub przynajmniej kupić) wszystko ${ }^{9}$,

co skutkuje tym, że najpierw jest ona najmłodszą królową Naboo, która w roli własnej dwórki porusza się bez ochrony, samodzielnie zawiązuje sojusz z Gunganami i przewodzi szturmowi w celu odbicia królewskiego pałacu i sali tronowej.

W Ataku klonów, po zakończeniu kadencji królowej, Padme zostaje senatorem reprezentującym swoją planetę w Senacie Republiki, po czym wbrew zasa-

8 Ibidem, s. 44; jeśli nie podano inaczej, przeł. K.K.

9 A. Harris, Future Girl, Young Women in the Twenty-First Century, London, 2004, s. 17. 
dom bezpieczeństwa udaje się z chroniącym ją Anakinem na Tatooine, by mógł zobaczyć się ze swoją matką, a następnie na Geonosis, gdzie niczym gladiatorka stoczy na arenie walkę i będzie mogła na niej pokonać chcącą ją pożreć bestię, a w finale, odrzucając wszelkie ograniczenia, w tajemnicy poślubia Anakina, gdyż w obliczu śmierci miłość staje się najważniejsza.

W Zemście Sithów natomiast — już jako żona sprzeniewierzającego się kodeksowi Jedi Anakina — Padme współtworzy Delagację 2000, która przekształci się później w Sojusz Rebeliantów. Jego ikoną będzie ich córka, w oryginalnej trylogii funkcjonująca jako księżniczka Leia, a dwie dekady później jako generał Leia Organa, co jest wskazaniem na zmianę elementu, na podstawie którego w uniwersum „Gwiezdnych wojen” będzie definiowało się tożsamość bohaterów. W oryginalnej trylogii było nim pochodzenie określane przez pokrewieństwo księżniczka, będąca córką królowej Amidali i wybrańca Anakina Skywalkera, a w trylogii sequeli to zdobyta przez nią pozycja społeczna.

W Mrocznym widmie (zgodnie ze średniowiecznym wzorcem) nastoletnia Padme jako królowa Amidala staje się obiektem miłosnej fascynacji wstępującego na rycerską ścieżkę Jedi siedmioletniego Anakina. Kiedy w Ataku klonów, po niemal dekadzie, bohaterowie spotykają się ponownie, dzieląca ich różnica wieku na skutek przeistoczenia się Anakina w młodzieńca i zrezygnowania Padme z ofiarowanego jej tronu zostaje zniwelowana, a wątek przedstawiający ich relację staje się ukształtowaną według paradygmatu melodramatu ${ }^{10}$ opowieścią o miłości zakazanej, konstytuowanej przez figurę pierwszego pocałunku, konflikt klas, racji i wartości, tragiczny los kochanków wyrażający się w niemożliwości spełnienia łączącej ich miłości w postaci baśniowego ,żyli długo i szczęśliwie” oraz śmierć obojga kochanków - fizyczną Padme oraz symboliczną Anakina.

Uczynienie Padme heroiną melodramatu zostaje podkreślone w warstwie wizualnej przez odwołanie się do ikonografii znanej z płócien prerafaelitów, zafascynowanych literaturą arturiańską, w sekwencjach ukazujących ją i Anakina na Naboo, czego kwintesencją jest ukazanie jej w scenie pogrzebu jako współczesnej Pani z Shalott. Jak pisze o tym Diana Dominguez,

decentralizacja postaci Padmy w całej trylogii prequeli wydaje się niesamowitą paralelą do tej młodzieńczej utraty siebie, szczególnie w kategoriach jej śmierci w Epizodzie III, z wizualnymi echami wiktoriańskich reprezentacji Ofelii i ukwieconą Panią z Shalott, podkreślającymi tragicznie romantyczną śmierć ${ }^{11}$.

Eksploatowanie w Zemście Sithów w wątku Anakina i Padme wyobrażenia kobiety o władzy jako uwięzionej w przyjętej roli społecznej i jednocześnie, co należy zauważyć, uczynienie jej bohaterką klasycznego melodramatu i obiektem

10 Zob. G. Stachówna, Niedole miłowania. Ideologia i perswazja w melodramatach filmowych, Kraków 2001, rozdz. 2. Formuła klasyczna, s. 31-49.

11 D. Dominguez, Feminism and the force. Disillusionment in galaxy far, far away, [w:] Culture, Identities and Technology in the Star Wars Films, red. C. Silvio, T.M. Vinci, Jefferson 2007, s. 110. 
uczuć Anakina niweluje potencjał postaci Padme do kształtowania przebiegu fabuły, wynikający z bycia przez nią manifestacją girl power, jak ma to miejsce w Mrocznym widmie. Jest to efektem, wskazanego już wcześniej w odniesieniu do oryginalnej trylogii, przywoływania i zarazem odrzucania w przestrzeni popkultury postulatów feminizmu, w czym manifestuje się jej swoista sprzeczność wynikająca z faktu, że jest ona równocześnie przestrzenią utrwalania i redystrybucji oraz rebelii wobec i destrukcji funkcjonujących paradygmatów.

\section{Rey — kiedy dziewczyna staje się Jedi}

W kontekście dwóch wcześniejszych cykli swoistą rewolucję w opowieści o przywróceniu pokoju, równowagi i harmonii w galaktyce przynosi dekadę późniejsza, trzecia trylogia (2015-), którą otwiera Epizod VII — znamiennie zatytułowany Przebudzenie Mocy - i kontynuuje Ostatni Jedi (Star Wars Episode VIII: The Last Jedi, reż. R. Johnson, USA 2017). W najnowszej odsłonie „Gwiezdnych wojen" moc działania i ocalenia świata przypisano postaciom kobiecym: opuszczonej przez rodziców Rey, generał Lei Organie, mechanik Rose Tico i wiceadmirał Amilyn Holdo, a bohaterów męskich naznaczono: rezygnacją (Han Solo, Luke Skywalker), popędliwością (Poe Dameron), sprzedajnością (DJ), bezwzględnością i agresją (Snoke, Kylo Ren), pozostawiając w niezmiennej funkcji i kształcie postacie nieludzi - robotów: C3PO, R2D2, BB-8 oraz Chewbacci i Yody.

Kiedy w kadrze pojawia się samotna postać Rey, jej kostium przywołuje ubiory nastoletniego Luke'a i siedmioletniego Anakina, scenografia — pustynna przestrzeń Jakku — do złudzenia przypomina Tatooine. Sytuacja, w jakiej nieświadoma swojego daru posiadaczka Mocy zostaje przedstawiona widzom, przez analogię jednoznacznie wskazuje, że w trzeciej trylogii to ona jest „wybrańcem”, lecz w odróżnieniu od wcześniejszych przedmiotem opowieści nie jest „bycie wybrańcem”, lecz „stawanie się nim” na skutek odkrywania przez nią i uznawania swojej Mocy. Ze względu na płeć bohaterki i przedmiot opowieści kreacja postaci Rey i jej wątku jest kontaminacją motywów w oryginalnej trylogii przypisanych postaciom Lei i Luke'a.

Wizerunek Rey jest kreowany na podstawie tych samych elementów co Lei i Padme - fryzury, kostiumu i broni. Jednakże w przeciwieństwie do swoich poprzedniczek nie jest ona odziana w sugerującą niewinność biel, kreującą ją na „piękność w opałach”, lecz analogicznie do Luke'a i Anakina — w bluzę i spodnie w kolorach ziemi. Jej fryzura nie jest kunsztowna, lecz swobodna, co ma podkreślać jej wolność i brak sformalizowanych funkcji. Orężem nie jest blaster, lecz włócznia, która czyni ją „,wędrowcem” i która dopiero z czasem, na skutek pierwszego pojedynku Kylo, zostanie wymieniona na otrzymany od Maz Kanaty miecz Anakina i Luke'a Skywalkerów, co będzie symbolizowało wstąpienie przez nią na ścieżkę rycerza Jedi. Swobodne, w stylu unisex, ubiór i fryzura Rey, tak odmienne od białych kostiumów i ikonicznych fryzur Lei i Padme, podkreślających ich ko- 
biecość, deseksualizują ją i kreują jej postać jako — przywołując określenie Katharine Wright - „,nową heroinę”, którą cechuje szczupła i pozbawiona kobiecych kształtów sylwetka właściwa wiekowi dojrzewania ${ }^{12}$. Skutkuje to definiowaniem tożsamości poza ograniczającą w kontekście społecznie uwarunkowanego wyboru realizowanych ról kategorią płci biologicznej i czyni wszystko możliwym. To ze względu na reguły określające kształt i przebieg fabuły opowieści o charakterze inicjacyjnym, której protagonistą — używając terminu Lorda Raglana — jest bohater tradycyjny ${ }^{13}$, umożliwia obsadzenie w jego funkcji nastolatki i zmianę zastanego androcentrycznego paradygmatu.

Rey jako protagonistka, analogicznie jak Luke i Anakin, jest sierotą zamieszkującą na pustynnej planecie, mającą wrażliwość na Moc i niezwykłą biegłość w pilotowaniu. Z tym że tożsamość Luke'a jako posiadacza Mocy jest znana, gdyż jego opiekunowie wiedzą, że pochodzi z rodu Skywalkerów; tożsamość Anakina jako wybrańca zostaje odkryta i ujawniona przez rycerza Jedi; natomiast tożsamość Rey jako dysponentki Mocy zostaje potwierdzona — analogicznie jak w wypadku Luke'a - dopiero otrzymaniem świetlnego miecza rycerza Jedi. Z tym że Luke otrzymuje od Bena Kenobiego przechowywany przez niego miecz swojego ojca Anakina, natomiast Rey zostaje „przyzwana” przez przechowywany przez Maz miecz Luke'a, co nie stanowi, tak jak ma to miejsce w opowieści o bohaterze tradycyjnym, potwierdzenia jej tożsamości i prawowitości jej dziedzictwa ${ }^{14}$, lecz prawo wynikające z posiadanego daru, który czyni ją „wybrańcem” ${ }^{15}$. Pozbawienie Rey pochodzenia, a przez to określających i wiążących ją emocjonalnych relacji, czyni ją podobną do pozbawionego nich Yody i rycerzy identyfikowanych jedynie dzięki swojemu orężu.

Rey, analogicznie jak Leia, zostaje „uprowadzona” przez „powtarzającego” ścieżkę Dartha Vadera Kylo Rena i tak samo jak ona poddana torturom, z tym że dziewczyna, odmiennie niż księżniczka, odpiera mentalny atak swojego przeciwnika i sama się uwalnia, co po popisie pilotażu jest drugą z manifestacji posiadanej przez nią Mocy. Trzecią będzie pojedynek o prawo do sukcesji dziedzictwa Skywalkerów i Jedi, stoczony na miecze świetlne z Kylo Renem.

Przyjęcie miecza i stoczenie pojedynku skutkuje wkroczeniem przez Rey na ścieżkę Jedi — odnajduje swojego mistrza, którym jest Luke, odbywa szkolenie, po raz kolejny konfrontuje się Kylo Renem i powraca, aby ocalić swoich przyjaciół i stanąć po stronie Ruchu Oporu. Jednakże tym, co odróżnia Rey od jej

12 K. Wrigth, The New Heroines, Santa Barbara, CA 2014, s. 125.

13 Lord Raglan, Bohater tradycyjny, przeł. I. Sieradzki, „Pamiętnik Literacki” 64, 1973, nr 1, s. $253-254$.

14 Szerzej tym pisałam w odniesieniu do bohaterów literatury i kina popularnego zob. K. Kaczor, Geralt, czarownice i wampir, Gdańsk 2006, s. 22-24

15 Analogiczny zabieg stosuje Andrzej Sapkowski, kreując postać Ciri jako protagonistkę sagi o wiedźminie; idem, Wieża Jaskótki, Warszawa 1999, s. 137-139. Szerzej o tym zob. K. Kaczor, op. cit., s. 53-54. 
poprzedników - Luke'a i Anakina - jest motywacja. Porzucona przez rodziców nastolatka, w przeciwieństwie do Anakina, będącego synem wyraźnie przedstawionej w opowieści matki, i Luke'a, syna legendarnego Skywalkera, podejmuje szkolenie, by uzyskać odpowiedź na pytanie o to, kim jest, i zdefiniować swoją tożsamość. W Imperium kontratakuje w czasie szkolenia u Yody Luke konfrontuje się ze swoją niewiarą, skutkującą poczuciem niemocy i rezygnacją, co zostaje przywołane w Ostatnim Jedi podczas szkolenia Rey; Anakin w Ataku klonów mierzy się ze swoją popędliwością i pragnieniem dominacji, co zostaje przywołane w postaci Kylo Rena. Celem szkolenia Luke'a i Anakina jest „zwalczenie” negatywnych aspektów ich osobowości, efektem zaś szkolenia Rey jest jungowska interioryzacja Cienia i odrodzenie Mocy na skutek uznania istnienia obu jej aspektów Czyni to tę opowieść bliższą duchowi Ziemiomorza Ursuli Le Guin ${ }^{16}$ niż oryginalnej trylogii George'a Lucasa.

\section{Zakończenie}

Ową swoistą rewolucję płci, do jakiej dochodzi w strukturze fabularnej „Gwiezdnych wojen”, można poddać refleksji w kontekście trzech aspektów. Pierwszym z nich jest zachodząca zmiana kulturowa, której wyrazem jest zakwestionowanie męskiego mitu bohaterskiego, co skutkuje feminizacją postaci ocalających świat. Świadectwem tego jest między innymi popularność filmowych adaptacji literatury dla młodych dorosłych: Igrzysk śmierci ${ }^{17}$, Niezgodnej ${ }^{18}$ czy też uczynienie protagonistką serialu Star Trek Discovery ${ }^{19}$ przybranej siostry Spocka Michael Burnham. Drugim jest obserwowana w kulturze współczesnej emancypacja pominiętych, czego wyrazem jest nie tylko kreowanie w przestrzeni kultu-

16 Na temat odwołań przez U.K. Le Guin do koncepcji Cienia C.G. Junga pisali między innymi M. Bianga, M. Stawicki, Mit i magia: Ursula K. Le Guin, „Anatomia Fantastyki” 1997, nr 3.

17 Igrzyska śmierci, cykl powieści dla młodzieży Suzanne Collins, który tworzą: eadem, Igrzyska śmierci (The Hunger Games, 2008), przeł. M. Hesko-Kołodzińska, P. Budkiewicz, Poznań 2009; eadem, W pierścieniu ognia (Cathing Fire, 2009), przeł. M. Hesko-Kołodzińska, P. Budkiewicz, Poznań 2009; eadem, Kosogłos (Mockinglay, 2010), przeł. M. Hesko-Kołodzińska, P. Budkiewicz, Poznań 2010; został zaadoptowany na duży ekran jako: Igrzyska śmierci (The Hunger Games), reż. G. Ross, USA 2012; Igrzyska śmierci: W pierścieniu ognia (The Hunger Games: Catching Fire), reż. F. Lawrence, USA 2013; Igrzyska śmierci: Kosogłos. Część 1 (The Hunger Games: Mockingjay Part 1), reż. F. Lawrence, USA 2014; Igrzyska śmierci: Kosogłos. Część 2 (The Hunger Games: Mockingjay Part 2), reż. F. Lawrence, USA 2015.

18 Trylogia powieści dla młodzieży Veroniki Roth, który tworzą: eadem, Niezgodna (Divergent, 2011), przeł. D. Zych, Warszawa 2012; eadem, Zbuntowana (Insurgent, 2012), przeł. E. Ratajczyk, E. Czub, Warszawa 2012; eadem, Wierna (Allegiant, 2013), przeł. M. Czub, Warszawa 2014; została zaadoptowana na duży ekran jako: Niezgodna (Divergent), reż. N. Burger, USA 2014; Seria Niezgodna: Zbuntowana (The Divergent Series: Insurgent), reż. R. Schwentke, USA 2015; Seria Niezgodna: Wierna (The Divergent Series: Allegiant), reż. R. Schwentke, USA 2016.

19 Star Trek: Discovery, CBS Television, USA 2018-. 
ry popularnej postaci wyposażonych w moc działania bohaterek, co przełamuje stereotypową antynomię męskiej aktywności i kobiecej pasywności, lecz także uczynienie pozytywnie waloryzowanymi bohaterami drugoplanowymi reprezentantów różnych narodowości i grup etnicznych. Trzecim aspektem — na skutek zakupu wytwórni LucasFilm - jest przejęcie praw do marki Gwiezdne wojny przez Walt Disney Company ${ }^{20}$, co skutkuje dokonanym przez nabywcę swoistym odświeżeniem serii w celu poszerzenia grupy odbiorców przez kreację nowych bohaterów, z którymi widzowie mogliby się zidentyfikować, i podporządkowania nowo nabytej marki polityce koncernu, który wykreował takie bohaterki, jak Merida Waleczna (Brave, reż. M. Andrews, B. Chapman, USA 2012) i Moana (Moa$n a$, reż. R. Clements, J. Musker, USA 2016), ukazując w ten sposób, że nie tylko młodzieńcy, ale też dziewczęta podejmują wędrówkę o charakterze inicjacyjnym.

Najbardziej wyczerpującej odpowiedzi na pytania o to, jakie są inspiracje i w jaki sposób postacie Lei, Padme i Rey odzwierciedlają zmiany kulturowe zachodzące od połowy lat sześćdziesiątych XX wieku na skutek kolejnych fal feminizmu, udzieliła przywoływana już Valerie Estelle Frankel w książce Star Wars Meets the Eras o Feminism, która swoim oglądem obejmuje spektrum tekstów kreujących uniwersum Gwiezdne wojny. Dowodzi ona, że kreacja postaci Lei była owocem drugiej fali feminizmu, której postulaty — przypomnijmy — koncentrowały się wokół społecznego równouprawnienia kobiet, prawa do samostanowienia i wyboru sposobów samorealizacji, co poskutkowało wzrostem aktywności zawodowej kobiet, łączeniem jej z byciem matką i marginalizacją, jeśli uwzględni się wzrost liczby rozwodów i kobiet samotnie wychowujących dzieci, roli żony, a w przestrzeni popkultury zaowocowało wizerunkami profesjonalistek — niezależnych od mężczyzn bohaterek, które równie sprawnie jak oni radzą sobie w sytuacji zagrożenia. Tym samym wykreowanie w „Gwiezdnych wojnach”, będącej rzeczywistą liderką Rebelii, księżniczki Lei przełamało swoistą barierę w kwestii kreowania bohaterek kina przygodowego i poprzedziło pojawienie się Ripley ${ }^{21}$, Sary Connor ${ }^{22}$, Czerwonej Sonii ${ }^{23}$, a dwie dekady później ocalającej Neo Trinity ${ }^{24}$.

Młodsza o dwie dekady Padme, z jednej strony sprawująca zrytualizowane funkcje królowej i senator Naboo, a z drugiej łamiąca protokół i procedury bezpieczeństwa czy też równie sprawnie jak Anakin i Obi-Wan Kenobi tocząca walkę z bestiami na arenie na Geonosis, jest manifestacją popularnego w latach dziewięćdziesiątych XX wieku hasła girl power ('moc dziewcząt'), kreującego nastolatki jako te, które mogą osiągnąć wszystko, czego zapragną. Tym samym,

${ }^{20}$ IAR, PAP, George Lucas oddat „Gwiezdne wojny” Disneyowi, „Polskie Radio”, https:// www.polskieradio.pl/5/3/Artykul/714944,George-Lucas-oddal-Gwiezdne-wojny-Disneyowi (dostęp: 10.01.2019).

21 Obcy - 8. Pasażer „,Nostromo” (Alien), reż. R. Scott, USA 1979.

22 Terminator (The Terminator), reż. J. Cameron, USA 1984.

23 Czerwona Sonja (Red Sonja), reż. R. Fleischer, Holandia 1985.

24 Matrix (The Matrix), reż. L. Wachowski, L. Wachowski, USA-Australia 1999. 
ze względu na jej młodzieńczy wiek, sprawność fizyczną, umiejętność walki i posługiwania się bronią oraz odwagę do podjęcia działań o charakterze antysystemowym, postać Padme w przestrzeni kultury popularnej antycypuje pojawienie się protagonistek literatury dla młodych dorosłych: Katniss Everdeen, Beatrice „Tris” Prior czy Clary Fray ${ }^{25}$.

Natomiast młodsza o kolejne dwie dekady postać Rey reprezentuje urzeczywistnienie idei tak zwanej czwartej fali feminizmu ${ }^{26}$, czyli ,przekroczenia” kategorii gender i rzeczywistego zniwelowania w odniesieniu do kobiet dystynktywnej roli płci biologicznej w zakresie wyboru środków autoekspresji, sposobów działania i przestrzeni aktywności w celu budowania, manifestowania i definiowania własnej tożsamości, co znajduje wyraz w warstwie ikonicznej i fabularnej trzeciej trylogii. Skutkuje to nie tylko obsadzeniem w roli wybrańca nastoletniej dziewczyny, której „niedojrzałość” — jak wskazuje V.E. Frankel — podkreśla jej potencjał samorealizacji w męskim świecie ${ }^{27}$, lecz przede wszystkim zmianą przedmiotu opowieści, którym w odróżnieniu od wcześniejszych trylogii w kontekście opowieści heroicznych nie jest „bycie przepowiedzianym wybrańcem” z racji urodzenia i dziedziczenia, lecz „stawanie się nim”, a celem nie jest synonimiczne z męskością dążenie do zniszczenia i unicestwienia za wszelką cenę, ale przypisane kobiecości ocalenie i odrodzenie.

\section{Bibliografia}

\section{Teksty}

Clare C., Miasto kości (City of Bones, 2007), przeł. A. Reszka, Mag, Warszawa 2009.

Clare C., Miasto popiołów (City of Ashes, 2008), przeł. A. Reszka, Mag, Warszawa 2009.

Clare C., Miasto szkła (City of Glass, 2009), przeł. A. Reszka, Mag, Warszawa 2010.

Clare C., Miasto upadtych aniołów (City of Fallen Angels, 2011), przeł. A. Reszka, Mag, Warszawa 2011.

Clare C., Miasto zagubionych dusz (City of Lost Souls, 2012), przeł. A. Reszka, Mag, Warszawa 2012.

25 Bohaterka cyklu powieści Dary Anioła autorstwa Cassandry Clare, który tworzą: eadem, Miasto kości (City of Bones, 2007), przeł. A. Reszka, Warszawa 2009; eadem, Miasto popiołów (City of Ashes, 2008), przeł. A. Reszka, Warszawa 2009; eadem, Miasto szkla (City of Glass, 2009), przeł. A. Reszka, Warszawa 2010; eadem, Miasto upadtych aniołów (City of Fallen Angels, 2011), przeł. A. Reszka, Warszawa 2011; eadem, Miasto zagubionych dusz (City of Lost Souls, 2012), przeł. A. Reszka, Warszawa 2012; eadem, Miasto niebiańskiego ognia (City of Heavenly Fire, 2014), przeł. A. Reszka, Warszawa 2014. Pierwszy tom serii został zaadoptowany na duży ekran jako: Dary Anioła. Miasto Kości (The Mortal Instruments: City of Bones), reż. Harald Zwarta, USA 2016.

26 A. Czarnacka, Czwarta Fala Feminizmu. Nowa rzeczywistość kobiet, „Nowa Orgia Myśli - Magazyn filozoficzno-kulturalno-polityczno-społeczno-literacki”, http://nowaorgiamysli.pl/ index.php/2018/02/12/czwarta-fala-feminizmu/ (dostęp: 10.01.2019).

27 V.E. Frankel, op. cit., s. 162. 
Clare C., Miasto niebiańskiego ognia (City of Heavenly Fire, 2014), przeł. A. Reszka, Mag, Warszawa 2014

Collins S., Igrzyska śmierci (The Hunger Games, 2008), przeł. M. Hesko-Kołodzińska, P. Budkiewicz, Media Rodzina, Poznań 2009.

Collins S., Kosogłos (Mockinglay, 2010), przeł. M. Hesko-Kołodzińska, P. Budkiewicz, Media Rodzina, Poznań 2010.

Collins S., W pierścieniu ognia (Cathing Fire, 2009), przeł. M. Hesko-Kołodzińska, P. Budkiewicz, Media Rodzina, Poznań 2009.

Roth V., Niezgodna (Divergent, 2011), przeł. D. Zych, Amber, Warszawa 2012.

Roth V., Wierna (Allegiant, 2013), przeł. M. Czub, Amber, Warszawa 2014.

Roth V., Zbuntowana (Insurgent, 2012), przeł. E. Ratajczyk, E. Czub, Amber, Warszawa 2012.

Sapkowski A., Wieża Jaskółki, superNOWA, Warszawa 1999.

\section{Opracowania}

Bianga M., Stawicki M., Mit i magia: Ursula K. Le Guin, „Anatomia Fantastyki” 1997, nr 3.

Campbell J., Potęga mitu, przeł. I. Kania, Signum, Kraków 1994.

Dominguez D., Feminism and the force. Disillusionment in galaxy far, far away, [w:] Culture, Identities and Technology in the Star Wars Films, red. C. Silvio, T.M. Vinci, McFarland \& Company Inc., Jefferson 2007, s. 109-133.

Frankel V.E., Star Wars Meets the Eras of Feminism. Weighing All the Galaxy's Women Great and Small, Lexington Books, Lanham 2018.

Harris A., Future Girl, Young Women in the Twenty-First Century, Routledge, London 2004.

Kaczor K., Geralt, czarownice $i$ wampir, słowo/obraz terytoria, Gdańsk 2006.

Kaczor K., Szyłak J., Gwiezdne wojny: Część IV - Nowa nadzieja (Star Wars Episode IV: A New Hope), [w:] J. Szyłak et al., Kino Nowej Przygody, słowo/obraz terytoria, Gdańsk 2011, s. $101-110$.

Kaczor K., Szyłak J., Star Trek (Star Trek: The Motion Pictures), [w:] J. Szyłak et al., Kino Nowej Przygody, słowo/obraz terytoria, Gdańsk 2011, s. 117-129.

Lord Raglan [właśc. FitzRoy Richard Somerset], Bohater tradycyjny, przeł. I. Sieradzki, „Pamiętnik Literacki" 64, 1973, nr 1, s. 253-254.

Mulvey L., Przyjemność wzrokowa a kino narracyjne, przeł. J. Moch, [w:] Panorama współczesnej myśli filmowej, red. A. Helman, Universitas, Kraków 1992, s. 95-107.

Stachówna G., Niedole miłowania. Ideologia i perswazja w melodramatach filmowych, Rabid, Kraków 2001.

Szyłak J., Kino Nowej Przygody — jego cechy i granice, [w:] J. Szyłak et al., Kino Nowej Przygody, słowo/obraz terytoria, Gdańsk 2011, s. 5-19.

Wrigth K., The New Heroines, ABC-CLIO, Santa Barbara, CA 2014.

\section{Filmografia}

Czerwona Sonja (Red Sonja), reż. R. Fleischer, Holandia 1985.

Dary Anioła. Miasto Kości (The Mortal Instruments: City of Bones), reż. Harald Zwarta, USA 2016.

Dracula (Bram Stoker's Dracula), reż. F.F. Coppola, USA 1992.

Frankenstein (Mary Shelley's Frankenstein), reż. K. Branach, USA 1994.

Gwiezdne wojny. Część I: Mroczne widmo (Star Wars Episode I: The Phantom Menace), reż. G. Lucas, USA 1999.

Gwiezdne wojny. Część II: Atak klonów (Star Wars Episode II: Attack of the Clones), reż. G Lucas, USA 2002. 
Gwiezdne wojny. Część III: Zemsta Sithów (Star Wars Episode III: Revenge of the Sith), reż. G. Lucas, USA 2005.

Gwiezdne wojny. Czesść IV: Nowa nadzieja (Star Wars Episode IV: A New Hope), reż. G. Lucas, USA 1977.

Gwiezdne wojny. Część V: Imperium kontratakuje (Star Wars Episode V: The Empire Strikes Back), reż. I. Kershneri, USA 1980.

Gwiezdne wojny. Część VI: Powrót Jedi (Star Wars Episode VI: Return of the Jedi), reż. R. Marquand, USA 1983.

Gwiezdne wojny. Część VII: Przebudzenie Mocy (Star Wars Episode VII: The Force Awakens), reż. J.J. Abrams, USA 2015.

Gwiezdne wojny. Część VIII: Ostatni Jedi (Star Wars Episode VIII: The Last Jedi), reż. R. Johnson, USA 2017.

Igrzyska śmierci (The Hunger Games), reż. G. Ross, USA 2012.

Igrzyska śmierci: Kosogłos. Część 1 (The Hunger Games: Mockingjay Part 1), reż. F. Lawrence, USA 2014.

Igrzyska śmierci: Kosogłos. Część 2 (The Hunger Games: Mockingjay Part 2), reż. F. Lawrence, USA 2015.

Igrzyska śmierci: W pierścieniu ognia (The Hunger Games: Catching Fire), reż. F. Lawrence, USA 2013.

Matrix (The Matrix), reż. L. Wachowski, L. Wachowski, USA-Australia 1999.

Merida Waleczna (Brave), reż. M. Andrews, B. Chapman, USA 2012.

Niezgodna (Divergent), reż. N. Burger, USA 2014.

Obcy - 8. Pasażer ,, Nostromo” (Alien), reż. R. Scott, USA 1979.

Seria Niezgodna: Zbuntowana (The Divergent Series: Insurgent), reż. R. Schwentke, USA 2015.

Seria Niezgodna: Wierna (The Divergent Series: Allegiant), reż. R. Schwentke, USA 2016.

Star Trek: Discovery, CBS Television, USA 2018-.

Terminator (The Terminator), reż. J. Cameron, USA 1984.

Vaiana: Skarb oceanu (Moana), reż. R. Clements, J. Musker, USA 2016.

\section{Źródla internetowe}

Czarnacka A., Czwarta Fala Feminizmu. Nowa rzeczywistość kobiet, „Nowa Orgia Myśli — Magazyn filozoficzno-kulturalno-polityczno-społeczno-literacki”, http://nowaorgiamysli.pl/index. php/2018/02/12/czwarta-fala-feminizmu/ (dostęp: 10.01.2019).

IAR, PAP, George Lucas oddat „, Gwiezdne wojny” Disneyowi, „Polskie Radio”, https://www.polskieradio.pl/5/3/Artykul/714944,George-Lucas-oddal-Gwiezdne-wojny-Disneyowi (dostęp: 10.01. 2019).

\section{When a girl becomes a Jedi: Between "old" and "new" Star Wars}

Summary

The subject of the article is to indicate the primary aspects of the creation and evolution of the heroines of the film trilogy from The Star Wars Universe in the example of three characters: Princess Leia, queen/senator Padme Amidala and the teenager Rey. Its purpose is to show, via the example of their creation, how feminism postulates are adapted and at the same time invalidated, which is re- 
flected in the ways of presenting them and the process of "revealing" their role function. This results in the emancipation of Star Wars heroines and taking over the functions of real leaders and commander-in-chief of the Republic and the Resistance Movement (Princess Lea - Queen/Amidala Ambassador - General Leia Organa) and a change in sex, being the main character of the story, the chosen one (Luke Skywalker - Anakin Skywalker - Rey Palpatine-Skywalker). At the same time, this process reflects cultural changes over the four decades that relate to women's social functioning.

The subject of the article is to indicate the primary aspects of the creation and evolution of the heroines of the film trilogy from The Star Wars Universe in the example of three characters: Princess Leia, queen/senator Padme Amidala and the teenager Rey. Its purpose is to show, via the example of their creation, how feminism postulates are adapted and at the same time invalidated, which is reflected in the ways of presenting them and the process of "revealing" their role function. This results in the emancipation of Star Wars heroines and taking over the functions of real leaders and commander-in-chief of the Republic and the Resistance Movement (Princess Lea - Queen/Amidala Ambassador - General Leia Organa) and a change in sex, being the main character of the story, the chosen one (Luke Skywalker - Anakin Skywalker - Rey Palpatine-Skywalker). At the same time, this process reflects cultural changes over the four decades that relate to women's social functioning. 